\title{
Does automatic tube compensation change metabolic parameters when added to pressure support mode during weaning?
}

\author{
I Karaca, A Comert, A Kuntman, K Demirag, M Uyar \\ From ESICM LIVES 2015 \\ Berlin, Germany. 3-7 October 2015
}

\begin{abstract}
Introduction
Artificial airway increases work of breathing (WOB) during weaning [1] which is one of the reasons for weaning failure [2]. Pressure support ventilation (PSV) decreases WOB and oxygen expenditure by decreasing resistance caused by artificial airway. Because inspiratory flow changes with every breath during PSV, it can not constantly compansate the changes in resistance caused by changes due to patient's inspiratory effort.

Automatic tube compensation (ATC) compensates the imposed WOB due to artificial airway. ATC adjusts the pressure inside the endotracheal tube therefore we hypothesized that when ATC is added to PSV, this compensation becomes better.
\end{abstract}

\section{Objectives}

To investigate the effects of addition of ATC to PSV on metabolic parameters.

\section{Methods}

After approval from University Ethics Committee and having patients' informed consents, patients ventilated with PSV mode more than 24 hours and met the weaning criteria were included. Patients having a respiratory rate $>35 / \mathrm{min}$, dyssynchrony with ventilator, body temperature $>38.3 \mathrm{oC}$, abnormal blood gas values, hemodynamic unstability were discarded. After obtaining normal blood gas values at the end of a stabilization period with PSV, metabolic parameters were measured for $30 \mathrm{~min}$ and average values of oxygen consumption (V02), carbondioxide production (VC02) and energy expenditure (EE) were recorded. Then ATC set at $100 \%$ support was added to PSV and after the similar adaptation period, measurements were repeated for $30 \mathrm{~min}$. Vital signs, respiratory mechanics and blood gas results were recorded at every $10 \mathrm{~min}$.

During the study period of 2 hours, patients were not disturbed by tracheal aspiration, position change and wound and catheter dressings. If needed, patient was discarded.

\section{Results}

Thirty-nine patients with an average age of $54,8 \pm 21,5$ years, APACHE II score of 20,7 $\pm 6,5$ and ideal body weight of $64,4 \pm 9,07 \mathrm{~kg}$ were enrolled. There were no significant difference in terms of hemodynamic parameters, blood gas values and respiratory mechanics between PSV alone and PSV + ATC. Metabolic measurements were also not different (Table 1).

\section{Conclusions}

The addition of ATC to a standart PSV based weaning did not improve metabolic parameters. More clinical studies are needed to clarify the effect of ATC as an adjunct measure during weaning.

Published: 1 October 2015

Table 1 Metabolic measurements

\begin{tabular}{llll}
\hline & PSV & PSV + ATC & p \\
\hline Energy expenditure $(\mathrm{kcal})$ & $1728,2 \pm 430,5$ & $1696,9 \pm 418,3$ & 0,195 \\
\hline Oxygen consumption $(\mathrm{ml} / \mathrm{min})$ & $259,3 \pm 68,7$ & $251,3 \pm 65,4$ & 0,129 \\
\hline $\begin{array}{l}\text { Carbondioxide production } \\
\text { (ml/min) }\end{array}$ & $201,0 \pm 55,5$ & $199,58 \pm 52,2$ & 0,646 \\
\hline
\end{tabular}




\section{References}

1. Haberthur C, et al: Additional inspiratory work of breathing imposed by tracheostomy tubes and non-ideal ventilator properties in critically ill patients. Intensive Care Med 1999, 25:514.

2. Cohen JD, et al: Extubation outcome following a spontaneous breathing trial with automatic tube compensation versus continuous positive airway pressure. Crit Care Med 2006, 34:682.

doi:10.1186/2197-425X-3-S1-A321

Cite this article as: Karaca et al: Does automatic tube compensation change metabolic parameters when added to pressure support mode during weaning? Intensive Care Medicine Experimental 2015 3(Suppl 1): A321.

\section{Submit your manuscript to a SpringerOpen ${ }^{\circ}$ journal and benefit from:}

- Convenient online submission

- Rigorous peer review

- Immediate publication on acceptance

- Open access: articles freely available online

- High visibility within the field

- Retaining the copyright to your article

Submit your next manuscript at $\gg$ springeropen.com 